\title{
Gorontalo
}

Journal of Public Health

Volume 2 - No. 2 - Oktober 2019

P-ISSN: 2614-5057, E-ISSN: 2614-5065

\section{Faktor Berhubungan dengan \\ Rendahnya Kunjungan Antenatal \\ pada Kontak Pertama Pemeriksaan Ibu Hamil (K-1)}

\section{Factors Influencing The Low Antenatal Visit in The First Contact of Pregnant Women Checking (K-1)}

\author{
Moh. Rivandi Dengo*, Idjrak Mohamad \\ Ilmu Kesehatan Masyarakat, Fakultas Kesehatan Masyarakat, Universitas Gorontalo, \\ Gorontalo, Indonesia \\ *email: moh.rivandidengo@gmail.com
}

\begin{abstract}
The coverage of Antenatal Care (ANC) visits in Gorontalo District during the last three years is as follows: the first visit of the pregnant women in 2015 reached $90 \%$, the visit in the following year in 2016 decreased to 76\%, and the visit in 2017 reached $89,86 \%$. This research aims to find out the factors related to the decrease of Antenatal Care in accordance with the decrease in the Antenatal Care visits in the first contact of pregnant women checking $K-1$ in the working area of Community Health Center Bongomeme Gorontalo District in 2018. The population of the current research was all pregnant women listed in Kohort pregnant women book in the Community Health Center Bogomeme in 2018 there were 163 pregnant women participated. The research design used was a cross sectional study approach. The obtained data were subsequently examined using chi-square test by referring to $p$ value $<0,005$. The research results shown that the parity variable of the pregnancy has $p$ value of 0,038 , pregnant women knowledge has $p$ value of 0,012 , and pregnant women job has $p$ value of 0,000. Thus, this variable has a parity of pregnancy, knowledge of pregnant women and occupation of pregnant women has a relationship with antenatal visits $(K-1)$, while family support variables with $p$ value of 0.478 means that this variable has no relationship with antenatal visits ( $K$ $1)$. The conclusion was the parity, pregnant women knowledge, and pregnant women occupation have the significant relationship with the antenatal care visits $(K-1)$, while the family support has no significant relationship with antenatal visits $(K-1)$. The pregnant women should maintain the pregnancy spacing, maintain the pregnancy health, and increase their knowledge.
\end{abstract}

Keywords; antenatal visits, parity, knowledge, occupation, family support

\begin{abstract}
Abstrak
Cakupan kunjungan Antenatal Care (ANC) di Kabupaten Gorontalo selama tiga tahun terakhir adalah cakupan kunjungan pertama ibu hamil (K-1) tahun 2015 mencapai $90 \%$, pada tahun berikutnya tahun 2016 terjadi penurunan yaitu $76 \%$ dan pada tahun 2017 mencapai 89,86\%. Penelitian ini bertujuan untuk mengetahui faktor-faktor yang berhubungan dengan rendahnya kunjungan Antenatal Care pada kontak pertama pemeriksaan ibu hamil K-1 pada Wilayah Kerja Puskesmas Bongomeme Kabupaten Gorontalo tahun 2018. Adapun populasi pada penelitian ini adalah seluruh ibu hamil tercatat di buku kohort ibu hamil Puskesmas Bongomeme tahun 2018 yaitu sebanyak 163 orang ibu hamil. Desain penelitian yang digunakan adalah pendekatan cross sectional study. Data yang diperoleh kemudian dilakukan uji statistic chi square dengan melihat nilai $p$
\end{abstract}


value $<0,005$. Hasil penelitian menunjukkan bahwa variable paritas kehamilan dengan nilai $p$ value 0,038 , pengetahuan ibu hamil nilai $p$ value 0,012 , dan pekerjaan ibu hamil nilai $p$ value 0,000. Artinya variabel paritas kehamilan, pengetahuan ibu hamil dan pekerjaan ibu hamil memiliki hubungan dengan kunjungan antenatal (K-1). Sedangkan variabel dukungan keluarga nilai $p$ value 0,478 ini berarti variabel dukungan keluarga tidak memiliki hubungan dengan kunjungan antenatal (K-1). Disimpulkan bahwa paritas, pengetahuan ibu, pekerjaan ibu ada hubungan yang signifikan dengan kunjungan antenatal K-I, sedangkan dukungan keluarga tidak memiliki hubungan yang signifikan dengan kunjungan antenatal (K-I). Ibu hamil agar lebih menjaga jarak kehamilan, menjaga kesehatan kehamilan, meningkatkan pengetahuan ibu hamil.

Kata kunci; kunjungan antenatal, paritas, pengetahuan, pekerjaan, dukungan Keluarga

\section{PENDAHULUAN}

Antenatal Care (ANC) adalah pelayanan kesehatan yang diberikan oleh tenaga kesehatan untuk ibu selama kehamilannya dan dilaksanakan sesuai dengan standar pelayanan yang ditetapkan dalam Standar Pelayanan Kebidanan (SPK). Tenaga kesehatan yang dimaksud di atas adalah dokter spesialis kebidanan dan kandungan, dokter umum, bidan dan perawat (Syafrudin dan Hamida, 2009).

Paritas, pengetahuan ibu, pekerjaan ibu dan dukungan keluarga merupakan faktor yang dapat mempengaruhi keaktifan kunjungan (K-1) pada ibu hamil. Paritas merupakan jumlah anak yang dilahirkan oleh ibu baik dalam keadaan hidup maupun mati. Paritas seorang ibu tidak aman untuk hamil dan melahirkan adalah pada kehamilan pertama dan paritas tinggi (lebih dari 3), paritas 2-3 merupakan paritas paling aman ditinjau dari sudut kematian maternal (Angraeny, 2015). Berdasarkan hasil penelitian yang dilakukan oleh Sari dkk (2015) menunjukkan paritas primigravida sebagian besar teratur dalam pemanfaatan pelayanan antenatal yaitu 15 responden $(75 \%)$ dan paritas multigravida sebagian besar tidak teratur dalam pemanfaatan pelayanan antenatal yaitu 19 orang $(65,5 \%)$. Pengetahuan sangat berperan terhadap perilaku seseorang. Berdasarkan hasil penelitian bahwa ibu yang berkunjung ke Puskesmas Wates Lampung Tengah yang memiliki pengetahuan kurang baik lebih besar yaitu 55\% (Evayanti, 2015). Pekerjaan adalah serangkaian tugas atau kegiatan yang harus dilaksanakan atau diselesaikan oleh seseorang sesuai dengan jabatan atau profesi masing-masing dan suatu cara seseorang yang mencapai tujuannya dalam memenuhi kebutuhan hidup. Berdasarkan hasil penelitian didapatkan sebanyak $52,5 \%$ responden yang berada di wilayah Kerja Puskesmas Wates Lampung Tengah memiliki pekerjaan (Evayanti, 2015). Dukungan keluarga dalam hal ini peran suami sangat penting untuk memotivasi istri selama masa kehamilan, terutama dalam hal menjaga kesehatan selama hamil serta turut mendampingi istri memeriksakan kehamilan rutin. Selain suami, dukungan orang tua ibu hamil ternyata juga memiliki pengaruh terhadap kunjungan ANC. Ini sesuai dengan hasil penelitian yang menyatakan bahwa sebanyak 39.3\% menyatakan suami merupakan anggota keluarga yang paling sering mengantar dan menemani responden melakukan kunjungan ANC rutin, 39.3\% responden lainnya menyatakan tidak pernah ditemani ketika melakukan kunjungan ANC selama masa kehamilannya (Dewi, 2014).

Survei Penduduk Antar Sensus (SUPAS) 2015 mengungkapkan AKI sebesar $305 / 100.000 \mathrm{KH}$, dan AKB sebesar 22,23/1000 KH. Indikator-indikator lain terkait kesehatan ibu dan anak juga mengalami peningkatan dalam akses walaupun masih memiliki tantangan dari sisi kualitas. Hasil Pemantauan 
Direktorat Kesehatan Keluarga tahun 2016, cakupan persalinan di fasilitas kesehatan sebesar 80,61\%, Kunjungan Neonatal Pertama sebesar 91,14\%, Kunjungan Antenatal 4 kali sebesar 85,35\% (Kemenkes, 2017).

Cakupan pemeriksaan kehamilan atau Antenatal Care di Indonesia (82\%) menurut WHO 2015 masih tertinggal dibandingkan negara-negara ASEAN yang lain seperti Korea Utara (95\%), Srilanka (93\%) dan Maladewa (85\%) dan angka kematian ibu di Indonesia masih tinggi di bandingan negara ASEAN (Association of Southeast Asia Nations) lainnya (Kemenkes, 2016).

Data profil kesehatan Indonesia tahun 2016 menunjukkan bahwa cakupan K-1 selama tahun 2011-2014 di Indonesia mengalami fluktuasi. Pada tahun 2011 cakupan K-1 yang berhasil dicapai Indonesia adalah sebesar 88,27\%, kemudian mengalami peningkatan di tahun 2012 sebesar 1,91\% menjadi 90,18\%. Akan tetapi cakupan K-1 mengalami penurunan di tahun 2013 menjadi $86,85 \%$. Angka tersebut menunjukkan bahwa cakupan K-1 di Indonesia belum mencapai target renstra 2013 sebesar 93\% (Walyani, 2015).

Data di Dinas Kesehatan Provinsi Gorontalo dari enam kabupaten dan kota, tentang cakupan K-1 angka terendah di Kabupaten Gorontalo Utara sebanyak 1.772 (88,08\%), kemudian Kabupaten Boalemo sebanyak 2.279 (81,92\%), Kabupaten Pohuwato sebanyak 2.314 (90,57\%), Kabupaten Bone Bolango sebanyak 2.818 (87,24\%), Kota Gorontalo sebanyak 4.165 (94,90\%), dan Kabupaten Gorontalo sebanyak 6.742 (89,86\%) (Profil Dikes Provinsi Gorontalo, 2017).

Cakupan kunjungan Antenatal Care (ANC) di Kabupaten Gorontalo selama tiga tahun terakhir adalah, cakupan kunjungan pertama ibu hamil (K-1) tahun 2015 mencapai 90\%, pada tahun berikutnya tahun 2016 terjadi penurunan yaitu 76\% dan pada tahun 2017 mencapai 89,86\% (Profil Dikes Kabupaten Gorontalo, 2017).

Dari data tiga tahun terakhir yang diambil dari Puskesmas Bongomeme, pada tahun 2015 dengan jumlah ibu hamil sebanyak 372 orang dengan cakupan K-1 mencapai 81,27\%, pada tahun 2016 cakupan K-1 sebanyak 87,3\% dari jumlah ibu hamil sebanyak 321 orang dan pada tahun 2017 cakupan K-1 sebanyak 88,6\% dari jumlah ibu hamil sebanyak 434 orang (Profil Puskesmas Bongomeme, 2017).

Pemanfaatan pelayanan antenatal oleh seorang ibu hamil dapat dilihat dari cakupan pelayanan antenatal, salah satunya yaitu cakupan kunjungan antenatal yang kurang dari standar minimal. Cakupan pelayanan antenatal dapat dipantau melalui cakupan pelayanan K-1 dan K-4. K-1 Kehamilan adalah kontak ibu hamil yang pertama kali dengan petugas kesehatan untuk mendapatkan pemeriksaan kesehatan seorang ibu hamil sesuai standar pada trimester pertama kehamilan, dimana usia kehamilan 1 sampai 12 minggu dengan jumlah kunjungan minimal satu kali. K-1 ini mempunyai peranan penting dalam program kesehatan ibu dan anak yaitu sebagai indikator pemantauan yang dipergunakan untuk mengetahui jangkauan pelayanan Antenatal serta kemampuan program dalam menggerakkan masyarakat (Purwandari, 2014). Dari uraian tersebut, maka penelitian ini bertujuan melihat variabel yang berkaitan dengan rendahnya kunjungan Antenatal Care pada kontak pertama pemeriksaan ibu hamil K-1.

\section{METODE}

Desain penelitian menggunakan observasional analitik, dengan pendekatan cross sectional study, dengan waktu penelitian yaitu dilaksanakan selama sebulan yaitu pada bulan Mei tahun 2018. Lokasi penelitian di Puskesmas Bongomeme Kecamatan Bongomeme Kabupaten Gorontalo Provinsi Gorontalo. Populasi sebanyak 163 orang ibu hamil, sampel dalam penelitian ini sebanyak 
163 ibu hamil dengan metode pengambilan sampel menggunakan exhaustive sampling yakni seluruh populasi dijadikan sampel.

Pengumpulan data diperoleh melalui kuesioner yang telah disusun berdasarkan tujuan penelitian yang dibuat. Rensponden pada penelitian adalah ibu hamil pada saat berkunjung ke Posyandu atau Poskesdes. Kategori variabel kunjungan pertama pemeriksaan ibu hamil (K-1) dengan kategori tidak berkunjung bila responden melakukan kunjungan pertama pada usia kehamilan > trimester pertama, sedangkan kategor berkunjung bila responden melakukan kunjungan pertama pada usia kehamilan trimester pertama (Sari dkk, 2018). Variable paritas kehamilan kategori paritas tinggi bila frekuensi kehamilan $>2$ kali, sedangkan untuk paritas rendah bila frekuensi kehamilan $\leq 2$ kali (Sari dan Efendy, 2017). Pengetahuan ibu kategori cukup apabila nilai jawaban benar responden $\geq 50 \%$ dari total pertanyaan yang diajukan, sedangkan kategori kurang apabila nilai jawaban benar responden < 50\% (Sari dan Efendy, 2017). Pekerjaan ibu dengan kategori bekerja apabila responden memiliki pekerjaan seperti Pegawai Negeri Swasta (PNS) dan swasta, sedangkan untuk tidak bekerja apabila responden ibu rumah tangga (IRT) (Notoatmodjo, 2010). Dukungan keluarga dengan kategori baik jika skor kuesioner dukungan keluarga $\geq 50 \%$, sedangkan untuk kategori kurang jika skor kuesioner dukungan keluarga $\leq 50 \%$ terkait pemeriksaan antenatal care (Dewi, 2014). Pengolahan data menggunakan uji chi cquare dengan derajat kepercayaan 95\% (nilai $a \leq 0.05$ ). Peneliti menggunakan program SPSS untuk proses pengolahan data dan analisis statistik.

\section{HASIL DAN PEMBAHASAN Karakteristik Subjek Penelitian}

Tabel 1. Distribusi Karakteristik Subjek Penelitian

\begin{tabular}{lcc}
\hline \multirow{2}{*}{ Karakterisitk } & \multicolumn{2}{c}{ Jumlah } \\
\cline { 2 - 3 } Umur (tahun) & $\mathrm{n}$ & $\%$ \\
$<20$ & 33 & 20,2 \\
$21-30$ & 105 & 64,4 \\
$31-40$ & 25 & 15,3 \\
Tingkat Pendidikan & & \\
Tidak Sekolah & 15 & 9,2 \\
SD & 45 & 27,6 \\
SLTP & 39 & 23,9 \\
SLTA & 36 & 22,1 \\
Kunjungan (K2) & & \\
Berkunjung & 144 & 88,3 \\
Tidak Berkunjung & 19 & 11,7 \\
Kunjungan (K3) & & \\
Berkunjung & 154 & 95,5 \\
Tidak Berkunjung & 9 & 5,5 \\
Kunjungan (K-4) & & \\
Berkunjung & 151 & 92,6 \\
Tidak Berkunjung & 12 & 7,4 \\
\hline Total & 163 & 100 \\
\hline
\end{tabular}

Berdasarkan Tabel 1, hasil analisis data menunjukkan karakteristik ibu yang meliputi umur, tingkat pendidikan, K-2, K-3, dan K-4. Distribusi frekuensi umur ibu tertinggi yaitu umur 21-30 tahun (64,4\%), tingkat pendidikan ibu sebagian 
besar berpendidikan Sekolah Dasar (SD) $(27,6 \%), \mathrm{K}-2$ tertinggi yaitu berkunjung sebesar $(88,3 \%)$, K-3 tertinggi yaitu berkunjung sebesar (95,5\%), K-4 tertinggi yaitu berkunjung sebesar $(92,6 \%)$.

Tabel 2. Analisis Variabel Kunjungan Antenatal pada Kontak Pertama (K-1), Paritas Kehamilan, Pengetahuan, Pekerjaan dan Dukungan Keluarga

\begin{tabular}{lcc}
\hline \multirow{2}{*}{ Variabel } & \multicolumn{2}{c}{ Jumlah } \\
\cline { 2 - 3 } & $\mathrm{n}$ & $\%$ \\
\hline Kunjungan (K-1) & 140 & 85,9 \\
$\quad$ Berkunjung & 23 & 14,1 \\
Tidak Berkunjung & & \\
Paritas Kehamilan & 16 & 9,8 \\
$\quad$ Tinggi & 147 & 90,2 \\
$\quad$ Rendah & & \\
Pengetahuan & 61 & 37,4 \\
$\quad$ Cukup & 102 & 62,6 \\
$\quad$ Kurang & 18 & 11,0 \\
Pekerjaan Ibu & 145 & 89,0 \\
$\quad$ Bekerja & & \\
$\quad$ Tidak Bekerja & 53 & 32,5 \\
Dukungan Keluarga & 110 & 67,5 \\
$\quad$ Baik & 163 & 100 \\
$\quad$ Kurang & & \\
\hline Total & & \\
\hline
\end{tabular}

Hasil analisis data menunjukkan faktor yang berhubungan dengan rendahnya kunjungan antenatal pada kontak pertama pemeriksaan ibu hamil (K-1) ditunjukkan pada Tabel 1. Distribusi frekuensi K-1 dari 163 responden tertinggi sebanyak $140(85,9 \%)$ responden yang berkunjung pada pemeriksaan ANC pada K-1. Menurut paritas kehamilan dari 163 responden sebanyak 147 $(90,2 \%)$ responden yang paritas kehamilannya rendah. Berdasarkan pengetahuan ibu dari 163 responden tertinggi sebanyak $102(62,6 \%)$ responden yang pengetahuannya cukup. Menurut pekerjaan dari 163 responden sebanyak $145(89,0 \%)$ responden yang tidak bekerja. Menurut paritas kehamilan dari 163 responden sebanyak $110(67,5 \%)$ responden yang dukungan keluarganya kurang.

\section{Faktor yang Berhubungan dengan Kunjungan Antenatal pada Kontak Pertama Kehamilan (K-1)}

Analisis bivariat pada penelitian ini adalah paritas kehamilan, pengetahuan ibu, pekerjaan ibu dan dukungan keluarga dengan kunjungan antenatal pada ibu hamil (K-1) ditunjukkan pada Tabel 3. Analisis bivariat menunjukkan paritas kehamilan yang tinggi lebih banyak yang melakukan kunjungan antenatal (K-1) yakni 68,8\% dibandingkan yang tidak melakukan kunjungan yakni hanya $31,2 \%$, hasil chi square diperoleh nilai $p$ value $=0,038$. Pengetahuan ibu yang cukup lebih banyak yang melakukan kunjungan antenatal (K-1) yakni $77,0 \%$ lebih besar dibandingkan dengan yang tidak melakukan kunjungan $\mathrm{K}-1$ yakni hanya $23,0 \%$, nilai $p$ value $=0,012$. Variabel pekerjaan ibu menunjukkan ibu bekerja lebih banyak yang tidak melakukan kunjungan $\mathrm{K}-1$ yakni 55,6\% lebih besar dibandingkan dengan yang melakukan kunjungan K-1 yakni hanya 44,4\%, nilai $p$ value diperoleh nilai 0,000. Variabel dukungan keluarga menunjukkan dukungan keluarga kategori baik lebih banyak yang melakukan kunjungan K-1 yakni 88,7\% lebih besar dibandingkan 
dengan yang tidak melakukan kunjungan K-1 yakni 11,3\%, meskipun analisis chi square menunjukkan nilai $p$ value $=0,478$.

Tabel 3. Analisis Faktor yang Berhubungan dengan Kunjungan Antenatal Ibu Hamil (K-1)

\begin{tabular}{|c|c|c|c|c|c|c|c|}
\hline \multirow{3}{*}{ Variabel } & \multicolumn{4}{|c|}{ Kunjungan Antenatal (K-1) } & & & \multirow{3}{*}{$\begin{array}{c}\rho \\
\text { value }\end{array}$} \\
\hline & \multicolumn{2}{|c|}{ Berkunjung } & \multicolumn{2}{|c|}{$\begin{array}{c}\text { Tidak } \\
\text { Berkunjung }\end{array}$} & \multicolumn{2}{|c|}{ Total } & \\
\hline & $\mathrm{n}$ & $\%$ & $\mathrm{n}$ & $\%$ & $\mathrm{n}$ & $\%$ & \\
\hline \multicolumn{8}{|c|}{ Paritas Kehamilan } \\
\hline Tinggi & 11 & 68,8 & 5 & 31,2 & 16 & 9,8 & \multirow{2}{*}{0,038} \\
\hline Rendah & 129 & 87,8 & 18 & 12,2 & 146 & 90,2 & \\
\hline \multicolumn{8}{|l|}{ Pengetahuan Ibu } \\
\hline Cukup & 47 & 77,0 & 14 & 23,0 & 61 & 37,4 & \multirow[b]{2}{*}{0,012} \\
\hline Kurang & 93 & 91,2 & 9 & 8,8 & 102 & 62,6 & \\
\hline \multicolumn{8}{|l|}{ Pekerjaan Ibu } \\
\hline Bekerja & 8 & 44,4 & 10 & 55,6 & 18 & 11,0 & \multirow{2}{*}{0,000} \\
\hline Tidak Bekerja & 132 & 91,0 & 13 & 9,0 & 145 & 89,0 & \\
\hline \multicolumn{8}{|c|}{ Dukungan Keluarga } \\
\hline Baik & 47 & 88,7 & 6 & 11,3 & 53 & 32,5 & \multirow{2}{*}{0,478} \\
\hline Kurang & 93 & 84,5 & 17 & 15,5 & 110 & 67,5 & \\
\hline Total & 140 & 85,9 & 23 & 14,1 & 163 & 100 & \\
\hline
\end{tabular}

Paritas adalah banyaknya jumlah kelahiran hidup yang dialami oleh seorang wanita. Ibu dengan jumlah paritas yang tinggi tidak terlalu khawatir dengan kehamilannya lagi sehingga menurunkan angka kunjungannya, sedangkan ibu dengan kehamilan pertama merasa ANC merupakan sesuatu yang baru sehingga ibu memiliki motivasi yang lebih tinggi dalam pelaksanaannya.

Dari hasil penelitian, berdasarkan uji chi square diperoleh nilai pvalue $(0,038$ $<$ a 0,05). Hal ini menunjukkan, ada hubungan yang signifikan antara paritas kehamilan dengan kunjungan antenatal (K-1). Hal ini disebabkan oleh masyarakat yang masih berpandangan hidup dimana memiliki banyak anak adalah sebuah anugerah dan membawa rejeki masih melekat erat meskipun demikian, masyarakat diberikan informasi tentang bahaya atau risiko mempunyai jarak kehamilan yang dekat ataupun paritas sebagai faktor risiko yang dapat membahayakan kesehatan ibu dan janin.

Penelitian ini sejalan dengan penelitian yang pernah di lakukan oleh Sari dkk (2015) yang menyatakan ada hubungan signifikan antara paritas dengan pemanfaatan pelayanan antenatal $(p$ value $=0,05)$. Penelitian ini tidak sesuai dengan penelitian yang pernah dilakukan oleh Vitriyani dkk (2012), dimana hasil penelitiannya menunjukkan bahwa tidak terdapat hubungan yang bermakna untuk variabel paritas kehamilan.

Variable pengetahuan ibu, berdasarkan uji chi square diperoleh nilai pvalue $(0,012<$ a 0,05). Hal ini menunjukkan ada hubungan yang signifikan antara pengetahuan ibu dengan kunjung antenatal (K-1). Hal ini dikarenakan dengan pengetahuan yang baik maka mereka akan lebih memahami akan pentingnya melakukan pemeriksaan antenatal sehingga mereka akan lebih teratur memeriksakan kehamilannya pada pelayanan kesehatan yang tersedia.

Penelitian ini sesuai dengan penelitian yang telah dilakukan oleh Tamaka (2013) dengan hasil uji statistik chi-square diperoleh nilai $\rho=0,031$. Pengetahuan ibu hamil memiliki hubungan dengan keteraturan pemeriksaan kehamilan. Penelitian yang telah dilakukan oleh Sari, dkk (2015) dengan hasil penelitiannya yaitu ada hubungan signifikan antara pengetahuan dengan 
pemanfaatan pelayanan antenatal $(p$ value $=0,001)$. Dengan pengetahuan ibu hamil yang baik, maka ibu hamil akan memahami betapa pentingnya melakukan pemeriksaan antenatal care pada pelayanan kesehatan. Penelitian ini tidak sesuai dengan penelitian yang telah dilakukan oleh Vitriyani dkk (2012) dimana hasil penelitiannya tidak memiliki hubungan yang bermakna untuk variabel pengetahuan.

Pekerjaan adalah serangkaian tugas atau kegiatan yang harus dilaksanakan atau diselesaikan oleh seseorang sesuai dengan jabatan atau profesi masingmasing dan suatu cara seseorang yang tujuannya untuk mencari uang terutama dalam memenuhi kebutuhan hidup. Pekerjaan dapat diklasifikasikan yaitu bekerja (buruh, tani, swasta, dan PNS) dan tidak bekerja (ibu rumah tangga dan pengangguran) (Notoatmodjo, 2010). Pekerjaan ibu yang dimaksudkan adalah apabila ibu beraktifitas ke luar rumah maupun di dalam rumah kecuali pekerjaan rutin rumah tangga. Ibu yang bekerja akan memiliki sedikit waktu untuk memeriksakan kehamilannya dan lebih banyak menghabiskan waktu untuk bekerja. Sedangkan ibu yang tidak bekerja, akan memiliki banyak waktu untuk memeriksakan kehamilan (Notoatmodjo, 2010).

Dari hasil penelitian yang didapatkan, berdasarkan uji chi square diperoleh nilai $\rho$ value $(0,000<\mathrm{a} 0,05)$. Hal ini menunjukkan, ada hubungan yang signifikan antara pekerjaan ibu dengan kunjung antenatal (K-1). Hal ini dikarenakan seorang ibu hamil yang bekerja cenderung akan menghabiskan waktu yang dimiliki untuk melakukan aktivitas pekerjaan yang dimiliki dibandingkan harus melakukan pemeriksaan kehamilan. Terutama pada masyarakat ekonomi menengah ke bawah, hal ini secara tidak langsung akan menurunkan motivasi ibu hamil dalam melakukan kunjungan pemeriksaan kehamilan. Penelitian ini tidak sesuai dengan penelitian yang telah dilakukan oleh Vitriyania dkk (2012) dimana hasil penelitiannya tidak memiliki hubungan yang bermakna untuk variabel pekerjaan.

Dukungan keluarga adalah sikap, tindakan dan penerimaan keluarga terhadap anggota keluarganya. Sebagai lingkungan yang terdekat dengan ibu hamil, dukungan dari keluarga memegang peranan penting dalam mempengaruhi psikologi dan motivasi ibu dalam melakukan perilaku kesehatan. Dari hasil penelitian yang didapatkan, berdasarkan uji chi square diperoleh nilai $\rho$ value $(0,478>$ a 0,05$)$. Hal ini menunjukkan, tidak ada hubungan yang signifikan antara dukungan keluarga dengan kunjung antenatal (K-1).

Penelitian ini sejalan dengan penelitian yang pernah dilakukan oleh Dewi (2014). Dengan hasil uji secara statistik menggunakan uji fisher didapatkan $p$ value sebesar 1.000 atau $p>0.05$ dimana hasil penelitian tidak adanya hubungan bermakna antara dukungan keluarga dengan frekuensi kunjungan ANC. Penelitian yang pernah dilakukan oleh Tating Nuraeni (2016) dimana hasil penelitian ini didapatkan nilai $p$-value 0,082 yang berarti tidak ada hubungan antara dukungan keluarga dengan kunjungan ANC ibu hamil. Hal ini tidak sesuai dengan teori bahwa walaupun keputusan berada di tangan suami ataupun keluarga. Akan tetapi, ibu tetaplah memiliki hak mutlak dalam pengambilan keputusan untuk kesehatan ibu dan janin yang ada dalam kandungannya. Apalagi bila dilatarbelakangi pengetahuan ibu yang sangat luas tentang kehamilan.

\section{PENUTUP}

Diketahui hasil penelitian diperoleh bahwa paritas, pengetahuan ibu pekerjaan ibu ada hubungan yang signifikan dengan kunjungan antenatal K-I, sedangkan dukungan keluarga tidak memiliki hubungan yang signifikan dengan kunjungan antenatal (K-I). Ibu hamil agar lebih menjaga jarak kehamilan, kesehatan kehamilan, meningkatkan pengetahuan ibu hamil serta keterlibatan 
keluarga terutama suami dalam memberikan dukungan kepada setiap ibu hamil dalam setiap melakukan pemeriksaan antenatal K-1.

\section{DAFTAR PUSTAKA}

Anggraeny E. 2016. Hubungan Tingkat Pengetahuan dan Status Paritas dengan Keteraturan Kunjungan Antenatal Care (ANC) pada Ibu Hamil Di RSUD Panembahan Senopati Bantul. Naskah Publikasi. Universitas 'Aisyiyah Yogyakarta. Yogyakarta.

Dikes Kabupaten Gorontalo. 2017. Profil Kesehatan Kabupaten Gorontalo. Gorontalo: Dinas Kesehatan Kabupaten Gorontalo..

Dikes Provinsi Gorontalo. 2017. Profil Kesehatan Provinsi Gorontalo. Gorontalo: Dikes Provinsi Gorontalo.

Dewi SM. 2014. Hubungan Dukungan Keluarga terhadap Frekuensi Kunjungan Antenatal Care pada Komunitas Slum Area Kelurahan Selapajang Jaya Kota Tangerang. Skripsi. Universitas Islam Negeri Syarif Hidayatullah. Jakarta.

Evayanti Y. 2015. Hubungan Pengetahuan Ibu dan Dukungan Suami pada Ibu Hamil terhadap Keteraturan Kunjungan Antenatal Care (ANC) Di Puskesmas Wates Lampung Tengah Tahun 2014. Jurnal Kebidanan. 1(2): $81-90$.

Kementerian Kesehatan RI. 2016. Analisis Determinan Kesehatan Gambaran Kebijakan Desentralisasi Kesehatan Indonesia. Jakarta: Kementerian Kesehatan RI.

2017. Pedoman Kebidanan Komunitas. Jakarta: Direktorat Jenderal Kesehatan Masyarakat.

Nuraeni T. 2016. Analisis Faktor yang Berhubungan dengan Rendahnya Kunjungan (K4) Ibu Hamil di Puskesmas Bambu Apus, Jakarta Timur. Jurnal Kesehatan Masyarakat. 1(4).

Notoatmodjo S. 2010. Promosi Kesehatan Teori dan Aplikasi. PT Rineka Cipta. Jakarta.

Puskesmas Bongomeme. 2017. Profil Puskesmas Bongomeme. Gorontalo: Puskesmas Bongomeme.

Sari GN, Fitriana S, Anggraini DH. 2015. Faktor Pendidikan, Pengetahuan, Paritas, Dukungan Keluarga dan Penghasilan Keluarga yang Berhubungan dengan Pemanfaatan Pelayanan Antenatal. Jurnal Ilmu dan Teknologi Kesehatan. 2(2):77 - 82.

Sari INN, Ramayani A, Baroya N. 2018. Perbedaan Kunjungan Antenatal Care Antara Ibu Hamil Peserta Progam Keluarga Harapan (PKH) Dan Bukan Peserta PKH Di Kecamatan Kalisat Kabupaten Jember. Jurnal IKESMA. 14(1): $34-44$.

Sari IP dan Efendy HV. 2017. Analisis Faktor Yang Berpengaruh Terhadap Kunjungan Antenatal Care. Jurnal Keperawatan dan Kebidanan. 9(1): 93 113.

Syafrudin dan Hamida. 2009. Kebidanan Komunitas, Buku Kedokteran EGC. Jakarta.

Tamaka C. 2013. Hubungan Pengetahuan Ibu Hamil Dengan Keteraturan Pemeriksaan Antenatal Care Di Puskesmas Bahu Kecamatan Malalayang Kota Manado. ejurnal Keperawatan. 1(1): 1-6.

Vitriyani E, Kirwono B, Firnawati AF. 2012. Faktor-Faktor Yang Berhubungan Dengan Pemeriksaan Antenatal Care (ANC) K1 Ibu Hamil Sdi Kecamatan Polokarto Kabupaten Sukoharjo. Jurnal Kesehatan. 5(2): 149-156. 